\title{
MAPPING MICUEL COVARRUBIAS ACROSS CULTURES AND DISCIPLINES
}

2 coser ecent years have seen a resurgence of interest in Miguel Covarrubias, a Mexican artist whose wide-ranging accomplishments span disciplines and media, the products of which have found their way into several recent museum retrospectives, and he rarely goes without mention in larger exhibits displaying twentieth-century Mexican art. ${ }^{1}$ Typically introduced as a modern renaissance man-and not without reason-Covarrubias's career included work as an illustrator, caricaturist, painter, muralist, anthropologist, archaeologist, ethnologist, stage designer, art historian and museographer. Such a figure can be explored from specific disciplinary perspectives, but so too does he provide an opportunity to consider the perennial academic discussions of area studies and interdisciplinarity more broadly. Covarrubias can aid in better understanding these divisions and can serve as a model of how they might be more productively understood.

1. I wrote and researched this essay while in Mexico as a Fulbright-Carcía Robles Postdoctoral Scholar during the 2018-2019 academic year. I would like to thank my host institution, the Universidad Popular Autónoma del Estado de Puebla (UPAEP), as well as the Archives and Special Collections in the libraries of the Universidad de las Américas Puebla (UDLAP) for their assistance in my research and for allowing me to include images from their collection in this article. An early draft of this essay was presented at the March 2019 conference sessions of the Southeastern Council on Latin American Studies (SECOLAS) held in Oaxaca, Oax., México.

Nathaniel R. Racine Texas AoM International University USA 
A brief overview of Covarrubias's work illustrates the difficulty of assigning a single disciplinary perspective to the study of his prolific body of work and its international trajectory. Beginning as a draftsman and illustrator in Mexico City, he eventually found commercial success and recognition upon moving to New York City at the age of nineteen, where his cartoons and caricatures of public figures came to be featured in the pages of such magazines as Vanity Fair and The New Yorker. Soon after, Covarrubias would become a well-known figure within the Harlem Renaissance, illustrating works such as Langston Hughes' Weary Blues (1926) and W. C. Handy's Anthology of the Blues (1926), along with a separate publication of his collected works under the title Negro Drawings (1927). ${ }^{2}$ He would continue to illustrate books of all types, including Zora Neale Hurston's Mules and Men (1935) and Frank Tannenbaum's Peace by Revolution: Mexico after 1910 (1933), as well as new editions of classic US novels such as Harriet Beecher Stowe's Uncle Tom's Cabin (in 1938) and Herman Melville's Typee (in 1935). His interests shifted toward a more deliberate and formal study of anthropology and ethnology, however, as he traveled around the world to study different cultures and ethnic groups. Covarrubias would publish the first modern in-depth study of traditional Balinese culture in Island of Bali (1937). Similarly, Covarrubias wrote the first comprehensive study of traditional cultures in Mexico's Isthmus of Tehuantepec in Mexico South: The Isthmus of Tehuantepec (1946), marking his enduring interest

One World The Americas Everywhere in the complexity and diversity of Mexican culture and its place in the Americas.

To study Covarrubias along strictly disciplinary lines would be to overlook a great deal of the meaning implicit in his work. In searching for some sort of synthesis among the many fields that take an interest in Covarrubias, the answer might be found

2. Covarrubias's illustrations in these works and others sometimes present problematic and stereotypical depictions of African American culture, as well as other peoples from elsewhere in the world. As Roberta Smith writes in a review of one recent retrospective on Covarrubias, many of his drawings "qualify as racist by today's terms. But mostly a benign if paternalistic joy at the world prevails" (Smith 2019: C23). This is a sensible observation and is a helpful perspective to adopt when studying any of Covarrubias's illustrated work. 
within Covarrubias's work itself. In it, he provides an example of how one might traverse the many disciplinary boundaries drawn within the academy. There has been a desire to cross these boundaries for the past generation or so, as American Studies has shifted toward the 'transnational' and 'hemispheric' study of US culture. One need only remember Shelly Fisher Fishkin's 2004 Presidential Address to the American Studies Association where she sees the discipline being at "a transnational crossroads of cultures" (2005: 43). Tracing the ways in which different ideas merge and subsequently split suggests the ways in which various cultural artifacts can be understood as part of a complex network of cultural interaction.

The desire to shift the perspective among Americanists was articulated a full decade before Fishkin's address by Carolyn Porter, who writes of her concern over "hyphenated American literatures" and the fragmentation of US literary study into many different academic departments (1994: 471). Rather than continuing to proliferate such boundaries, Porter advocates "dissolv[ing] the disciplinary and departmental lines," seeking scholarship that "offers the promise of approaching America's literatures as the very opposite of parochial or insulated or exceptional, without thereby assuming a global or imperialist perspective" (521). The implication is that US culture can be read and understood in multiple contexts at the same time.

It is a difficult balance to strike and it has continued to preoccupy scholars in more recent years. Perhaps the most compelling approach is found in a review article by Laura Dassow Walls titled "Literature, Geography, and the Space of Interdisciplinarity" (2011). In it, Walls describes the importance of considering literary study across disciplines, writing that "the boundary separating the disciplines of literature and geography is itself a geographical question, a problem of form which is simultaneously a problem of history" (2011: 871). In calling for literary study to incorporate a geographic perspective, Walls cautions against thinking that larger scales, such as the international, are dominant over the smaller scales, such as the local and regional. She calls this idea "scale-jumping," as it requires an awareness that these different 'scales' of human association exist simultaneously and only through one another. It 
is geography that serves to illustrate the ways in which these scales constantly intersect. The same ideas are relevant beyond US literary study and can be applied to American Studies more generally.

One thread connecting Porter to Fishkin to Walls is the desire to overcome the assumed hierarchy of geographic scales that privilege the international over the continental over the national over the regional over the local. What Walls makes clear in her essay is that they must always be understood as coexisting. The 'larger' scale of the international cannot be understood as dominating or subsuming the 'smaller' scales, such as the regional. Understanding and incorporating key ideas from geography to expand the scope of inquiry in the humanities adds a contextual richness, both spatial and historical.

These cultural-geographical associations are evident throughout the many maps Covarrubias would produce and which can be found as illustrations in several of the books to which he contributed. He would eventually elaborate upon these ideas more fully in his own books on comparative anthropology in the Americas later in his career. Within his lager body of work are stand-alone mural projects, the most ambitious being a sequence of mural-maps titled Pageant of the Pacific (1939), commissioned by the Golden Gate International Exposition, held in 1939-1940 to celebrate the thenrecent completion of the San Francisco Bay and the Golden Gate Bridges (in 1936 and 1937, respectively). The exposition promoted unity among the countries of the Pacific Basin, celebrating their

One World The Americas Everywhere specific cultures and unique contributions to an interconnected world economy-and Covarrubias's mural-maps would decorate the central "Theme Building" of the exposition. His maps would provide a "graphic presentation" of the "central idea of the Exposition [of] [...] Pan Pacific cultural and commercial reciprocity" and the murals would be placed in the centrally-located "Pacific House" (Youtz 1938). Covarrubias was selected because of his previous writings and maps and the accessible style of the illustrations. In his prefatory note to a commemorative booklet published the year after the exposition, Dr. Ray Lyman Wilbur, president of the Pacific House corporation, ${ }^{3}$ wrote: "Covarrubias is an ethnolo-

3. The Pacific House Corporation was established after the closing of the Golden Gate International Exposition in order to continue the work 
gist and anthropologist, subtle and sensitive to the unrecorded past of unknown peoples, with a humorous, penetrating perspicacity of contemporaneous life, and a wide knowledge of the governmental forms and trade relations, of the moving forces, that bind peoples together or sever their relations" (Wilbur 1940). Covarrubias's reputation as an ethnologist and anthropologist had by then been established through the success of Island of Bali, and his sense of humor and shrewd observation of the contemporary scene could be found throughout his earlier caricatures. Both qualities are seen in operation in the six mural-maps that he would produce for Pacific House. Many scholars point to the importance of these maps as being central to understanding Covarrubias's larger body of work and the maturation of his early ideas regarding cultural diffusion between Asia and the Americas.

Each mural-map considers a different aspect of the "cultural and commercial reciprocity" among cultures of the Pacific region and their titles, as presented in the booklet mentioned above, are: Peoples of the Pacific, Flora and Fauna of the Pacific, Art Forms of the Pacific Area, Economy of the Pacific, Native Dwellings of the Pacific Area and Native Means of Transportation in the Pacific Area. Each map was reproduced as a full-color plate in a booklet published after the exposition closed. Also titled Pageant of the Pacific (1940), the document looks back upon the exposition and toward the future of its pan-Pacific vision.

To help understand the ideas at play in Covarrubias's maps for Pacific House, it is worth considering some of the key concepts being developed in the field of human geography around the same time. Geography, as a discipline with its own theories and methods, takes as its purview the relationship between

of "extend[ing] the knowledge of the countries of the Pacific Basin-to create those friendly relations which make for a wider understanding between peoples," as Wilbur writes in the same introduction. Although at odds with current events in both Europe and Asia, an optimism in the goals of the fair is also articulated: "The possibility of the stark tragedy that is now overwhelming the world was sensed in the early days of the Fair, when the thought of making the themes of the 1939 Exposition, A Pageant of the Pacific, a living reality first took place. It was hoped then that the idea would become an entity which would live after the Exposition closed its gates" (Wilbur 1940). 
human society and the physical environment. Within the United States, the discipline underwent a major shift during the first part of the twentieth century, moving from a deterministic to a possibilistic view of culture. In geography, environmental determinism emphasizes the role of the environment in shaping those cultures inhabiting it, while environmental possibilism emphasizes the role of cultures in shaping their environment through use and habitation. As such, possibilism recognizes the agency of human cultures by focusing on how they have acted on the landscape by modifying its character and being limited by its available resources-in effect, living in it through the creative interpretation of the possibilities found there. These concepts are at the foundation of cultural geography as a discipline.

Within the United States, these ideas were first articulated by Carl 0 . Sauer in his foundational essay, "The Morphology of Landscape" (1925). It is here that he clearly refocuses geography's attention on human beings, writing, "Geography is distinctly anthropocentric, in the sense of value or use of the earth to man" (1969: 325). The conclusion of his essay provides a succinct overview of why Sauer rejects environmental determinism which, he writes, is based on a "narrowly rationalistic thesis." He continues:

One World

The Americas

Everywhere

[It] conceives of environment as process, and some of the qualities and activities of man as products. The agency is physical nature; man responds or adapts himself. Simple as the thesis sounds, it incurs continually grave difficulties in the matching of specific response to specific stimulus or inhibition. [...] What man does in an area because of tabu or totemism or because of his own will involves use of environment rather than the active agency of the environment. (1969: 349)

Central to "The Morphology of Landscape" is the concept of the "cultural landscape." To fully understand the physical landscape, the geographer must first understand the culture that inhabits a given area which, in this context, denotes "the sum of all natural resources that man has at his disposal" (1969: 325-326). Such an approach offers "a strictly geographic way of thinking about culture; namely, as the impress of the works of man upon the area" (326). By extension, the idea of the "cultural landscape" would also incorporate the ways in which a given culture understands, describes and characterizes the environment it inhabits. 
In the modernizing world of the early twentieth century, competing views of the same landscape would inevitably encounter one another. The interpretation of a given landscape enters the realm of abstract myth and symbol (incorporating "tabu or totemism"). Such uses are as important for a culture as the ways in which it physicallychanges the landscape. In the end, "the cultural landscape [...] is subject to change either by the development of a culture or by a replacement of cultures" (333). These few excerpts help in understanding Sauer's contribution in "The Morphology of Landscape" which, in its entirety, provides a systematic articulation of cultural geography and its methods. As a document, it would be integral to the discipline for much of the twentieth century, most notably through the influence of the "Berkeley School" of geographers at the University of California, Berkeley, which was led by Sauer himself for some thirty years (Parsons 2009: 4-5).

The shift in approach to the study of culture represented by Sauer and his students was not confined to the academy, nor was it strictly confined to the discipline of geography. For example, in one recent study, The Geopoetics of Modernism (2015), Rebecca Walsh explores the ways "in which literary modernism and geographical knowledge co-evolved" during the interwar period (2015: 3). Focusing her analysis on modernist poetry, ${ }^{4}$ Walsh examines how environmental determinism pervaded the culture at large through such publications as National Ceographic Magazine and other popular media, emphasizing the difficulty in breaking away from causal understandings of environment that suggest "landscape first, culture second" (15). The literary engagement with these issues suggests the wider context in which society was coming to terms with the complexities of human culture and cultural interaction during the first half of the twentieth century. Engagement with various aspects of cultural geography, balanced against a preoccupation with the modernizing world, allowed certain writers, artists and intellectuals to depart from conventional paradigms through the aid of the evolving socio-scientific discourse.

In the case of Covarrubias, this context is more than happenstance. In 1938, when he was commissioned to paint the sequence

4. Walsh's central figures are Walt Whitman, Helene Johnson, Langston Hughes, Gertrude Stein and H.D. 
One World

The Americas

Everywhere

of mural-maps for the Golden Gate International Exposition, the template for these maps, known as the "Van der Grinten Projection," was selected by Sauer himself. At the turn of the century, when this projection was still relatively new, E. A. Reeves, map curator and instructor of surveying for the Royal Geographical Society, provided a practical assessment of the projection, explaining its merits and defects in practical terms. Reeves writes, "[t]here can be little doubt that Mr. Van der Grinten's projection possesses advantages over the others [the Mercator and Mollweide projections] for special purposes, such as representing the geographical distribution of natural phenomena, oceanic circulation, trade routes, etc." (1904: 671). At the same time, these qualities have their educational disadvantages, potentially misleading the student given the exaggeration of its polar regions. To avoid this, Reeves suggests omitting the northern and southern poles from the map, thereby maintaining its advantages in "conveying a far more accurate idea of relative areas" (671). This is exactly what was done in designing the template for the Pacific House murals-and it is that template from which Covarrubias worked.

In his introductory note to the descriptive booklet published to commemorate the Pageant of the Pacific, Covarrubias writes, "the Van Der Grinten projection was chosen because it showed the land areas in a proportionate manner without the distortion and exaggeration of certain lands in detriment to others seen in the more familiar projections" (Covarrubias 1940). Covarrubias's introductory notes-in which he also offers his thanks to Sauer and the Department of Geography at Berkeley-point to the ways in which the qualities of the projection function in his Pageant of the Pacific. Covarrubias's primary concern is with the "geographical distribution" of the peoples, flora and fauna, art forms, economy, dwelling types and transportation of the Pacific region. ${ }^{5}$ What

5. Although he omits trade routes (including from the fourth map, Economy of the Pacific), draft materials that include such routes do exist among Covarrubias's papers held by the Universidad de las Américas Puebla in their Archivo Miguel Covarrubias. While incomplete, they nevertheless include similar attention to details as the other maps, further demonstrating how he envisioned the Pacific area spilling into the Atlantic and Indian Oceans. Nonetheless, trade routes were included in a leaded-glass window in the Pacific House on its north wall. 
is most striking in the context of Covarrubias's maps, however, is not the use of the Van der Grinten projection, but in shifting it to center on the Pacific Ocean and relegating all continental land masses to its perimeter.

Following this brief introduction, Covarrubias continues with a brief outline of "The Pacific Area" that discusses this unusual orientation. He writes:

A map centered on the Pacific Ocean is apt to be unfamiliar to us, accustomed since childhood to see world-maps with a strong emphasis upon the Atlantic, with Europe on one side, America on the other. For this reason, and because of a certain prejudice, prevalent until recently, for peoples and cultures other than those of European, 'White', origin, the Pacific Ocean has come to be regarded in the popular mind as a vast expanse of water bordered by and dotted with remote, exotic peoples, and as a barrier rather than the link that it is, between the peoples, cultures and economy of the countries of the Pacific Area. (1940)

The sentiment expressed here is perhaps no less relevant today than when Covarrubias first wrote it. ${ }^{6}$ In attempting to correct for these distances in the "popular mind" and its tendency to exoticize Pacific cultures, Covarrubias contributes to "an important aspect of [the] educational agenda" of the exposition, as anthropologist Nancy C. Lutkehaus argues in her essay on the murals (2014: 121). While the Golden Gate International Exposition may have emerged from the problematic tradition of world's fairs of the nineteenth century and their "racist agendas and imperialist functions" (111), the vision it represented was "transitional [...] or, at the very least, a more complex cultural artifact than other earlier fairs" (111-112). It is through Covarrubias's mural-maps that, however much the whole event "still promoted the hegemony of American economic, technological, and social superiority [...] the images of transpacific connections that Miguel Covarrubias depicted in the six murals [...] actually helped to make explicit new ideas about the interconnections between the indigenous peoples of what we now call the Pacific Rim" (128-129). Before continuing the discussion of the educational qualities of the Pageant

6. Nancy C. Lutkehaus begins her own discussion of the Pageant of the Pacific by invoking President Barack Obama's 2012 remarks that “. [...] the United States is and always will be a Pacific nation."' (109). 
of the Pacific, however, it is necessary to discuss the mural-maps in greater detail.

After his introductory notes and explanation of the "Pacific Area," Covarrubias continues the booklet by providing a short but detailed descriptive essay for each map, which function as interpretive aids. For example, Covarrubias writes that Peoples of the Pacific Area

attempts to roughly divide the cultures of the Pacific into general geographical areas where characteristic cultures exist, whether ancient or contemporary. In many cases these cultures are superimposed or overlap and the outlines shown here should only be taken as a general guide for their situation and not as a study of their relationship. (1940)

The study of their relationship should instead come through observing the qualities and characteristics of the cultural artifacts of these diverse peoples, only some of whom are depicted across the larger Pageant of the Pacific. As Covarrubias notes, the geographic areas on these mural-maps are "general" and he has selected representative examples both "ancient and contemporary." Here, Covarrubias alludes to his lifelong engagement with the study of comparative anthropology. Although not yet fully articulated, his ideas on the topic would become his life's work, beginning to take form in Mexico South and eventually formulated in The Eagle, the Jaguar, and the Serpent (1954), which was the first of three volumes that would present a Pan-American

One World The Americas Everywhere study of the peoples of North, Central and South America from a comparative, diffusionist perspective. The second volume, Indian Art of Mexico and Central America (1957) would be published posthumously and the third, on South American indigenous cultures, would remain unfinished. (see fig. 1 on the facing page).

The maps found within Pacific House only hint at Covarrubias's later ideas and, while important in understanding the larger trajectory of his career, they are interesting in their own right and in the context of the overall message and objectives of the exposition. The educational component of these maps functions both in terms of the pan-Pacific unity proposed by the Golden Gate Exposition, but also in terms of Covarrubias's developing theories of cultural diffusion in the Americas-and the desired impact 


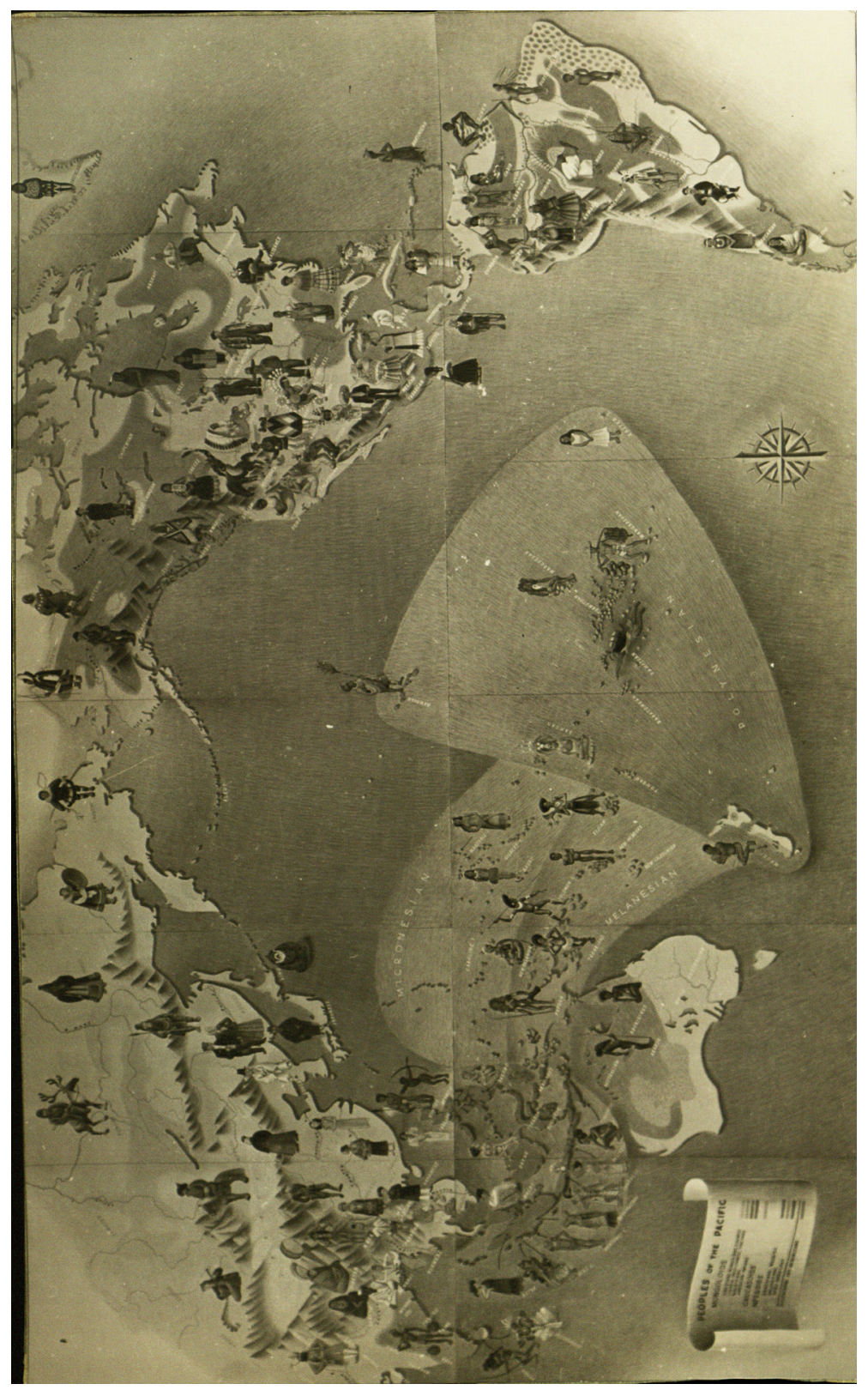

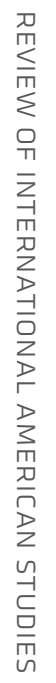

Nathaniel R. Racine Texas AaM International University USA

Fig. 1. Miguel Covarrubias, Peoples of the Pacific from Pageant of the Pacific, 1940. Courtesy of the Archivo Miguel Covarrubias. Sala de Archivos y Colecciones Especiales, Dirección de Bibliotecas, Universidad de las Américas Puebla. 
is clearly suggested in a book for young readers, A Trip to the San Francisco Exposition with Bobby and Betty (1939), by San Francisco author and journalist, Joseph Henry Jackson.? Upon entering Pacific House and seeing the murals, the astute young Bobby immediately notices the design and focus of the six mural-maps. He asks his father, "Dad [...] why are these so different from other maps? They don't look the same at all. I can tell the United States, for example, and South America and the Orient too, but it all seems to be in different proportions somehow. Why is that?" (Jackson 1939: 70). The proud father explains:

Yes, these maps are different. And the reason is that they're all drawn from a different starting place from the ones you're used to. [...] Instead of working that way and considering the whole world, the artist took just the Pacific Area and found the center of it. Then he drew his map from that center-just as if the Pacific Area was all the world there was! Geographically, in relation to the rest of the world, this map wouldn't be of any use. But it does show the relationship between the parts of the Pacific Area and far better and more truly than a map which has to consider the whole world. (70-71)

The lesson is quickly absorbed and Bobby continues observing Covarrubias's illustrations on the maps and, once again, his father explains their unique quality:

[...] what the artist was after in this case was not merely geography. These 'maps' (you have to call them that, though it isn't the right word, really) are made to show not just geography but history. And not just

One World The Americas Everywhere history, either, in the way most of us have always learned it-in terms of dates and time-but history in terms of the culture of the different races around the Pacific. (71-72)

While the father displays certain prejudices and a limited understanding of certain concepts, the reader can forgive him these shortcomings, as he encourages an open-minded perspective in his two children, inspiring them to approach the murals with

7. Jackson's book was part of the series, Seeing America with Bobby and Betty, in which the two eponymous children also travel to the cities of Washington and New York, as well as the New York World's Fair. They were written by well-known figures of the time, including Lowell Thomas-and the story of their trip to Washington, DC, was written by a certain "Mrs. Franklin D. Roosevelt." 
their imaginations-and this is exactly what Bobby and Betty do, moving "from one wall to the next, following the whole story of civilization in the Pacific, tracing the migration of peoples [...] They saw how the American Indian developed one kind of civilization and how the Aztec and the Maya and the Inca developed entirely different kinds" (72). Coaxed along by their father, once immersed among the mural-maps, "Bobby and Betty found it quite different and the most interesting thing they had ever seen or done. In fact Mother and Dad had a hard time waking them out of the half-dream into which these extraordinary maps had put them" (72). Surely Covarrubias would have been pleased by these two young students and their perceptiveness.

Part of what enthralls Bobby and Betty is what art historian and museum director Sylvia Navarrete describes as the "synchronic narrative treatment" of the murals (qtd. In López Casillas, et al. 2005: 101). The Pageant of the Pacific depicts a non-linear history of Pacific cultures told through the presentation of general culture areas and representative cultural artifacts. Each map individually suggests complex structures of historical-geographical exchange and, together, as a set of six mural-maps, form an iterative sequence among themselves.

Part of any interpretation of Covarrubias's project in Pacific House should consider the original architectural context of these murals. As Lutkehaus writes, the exposition adopted a "Pacific Unity" style for the exterior of the fair's buildings that "drew on the monumental architecture of the archaic cultures found on the Pacific Rim" (2014: 118). Alternatingly described by critics as either "fun" or as "fakery" (qtd. in Lutkehaus 2014: 120), the fairgrounds were composed of an eclectic blend of architectural styles filtered through a contemporary streamline moderne aesthetic (119).

While a fitting atmosphere in which to find Covarrubias's murals, it is also important to consider the interior of these buildings. The basic layout of the interior of Pacific House would have contributed to the experience of these mural-maps, as all murals engage their audiences in a manner different from easel paintings or other artwork created on a smaller scale-and a mural sequence even more so. The experience of viewing 
One World

The Americas

Everywhere

a mural involves the audience entering a spatial "envelope," as Leonard Folgarait writes in his book, Mural Painting and Social Revolution in Mexico (1998). He writes, "murals describe, construct, and somewhat control the human viewing subject. Upon crossing into a mural's field of engagement, the status of the viewer changes from spectator to participant and her or his action within this spatial envelope is then seen in terms of that state of envelopment" (1998: 28). When confronted by multiple panels of a mural sequence in a large room, the viewer is able to move among the different images in any number of directions. It is fundamentally about size and scale and murals allow their audience to move "through space, to and from an image of proportions that can fully occupy the field of vision to become a 'place'" (28).

The 'place' created inside Pacific House was composed of more than Covarrubias's maps. In the center of its floor was a relief map of the Pacific Basin playfully designed to include "four whales in the middle of the fountain, spouting water to feed the Pacific Ocean of the elliptical basin with its relief surface" (James and Voland 1941: 101). The spirit of this design matched the cartoon-like aesthetic found in Covarrubias's mural-maps and, together, they served the vision of the exposition and its educative goals. One imagines visitors entering the building through different entrances, greeted by the maps on the walls above the other doorways. They do not encounter the mural-maps in the sequence presented in the booklet discussed above, as there is no fixed sequence of viewing implied by the space itself. One can move freely around the fountain in any direction, looking at the murals above from different angles and distances while listening to the splashing of the fountain. One is enveloped by representations of the Pacific Ocean and its component parts. It is a 'place' dedicated to the Pacific, earning its name, "Pacific House." In moving about within the room, the viewers must construct their own understanding of how these cultures all fit together through associative observation. There can be no linear narrative logic to the maps and their very display conveys the idea that the peoples, the flora and fauna, the art 
forms, the economy, the dwelling types and the transportation of the Pacific have been and will continue to be interconnected. These images are the raw material through which open-minded observers such as Bobby and Betty, through their "half-dream" and imaginative faculties, begin to formulate patterns and connections suggested through-but in no way dictated by-Covarrubias's compositions. As such, visitors are welcomed to a place where they create their own spontaneous study of comparative material culture to which Covarrubias had begun to devote his own professional energies. One begins to see how the map projection, the mission of the exposition, the floorplan, Covarrubias's illustration style and his anthropological theories, all merge to create a larger vision.

By not committing his murals or his audience to a linear narrative structure, Navarrete suggests that Covarrubias "extends the informative function and the poetic interpretation: he embraces geography, tourism, production, and statistics, as well as folklore, religion, and festive exaltation. Beyond their commercial character and allegorical expression, his maps are genuine modern codices and occupy a distinguished place in Mexican muralism" (qtd. in López Casillas, et al. 2005: 101). Covarrubias's use of color, emblematic human figures and representative material artifacts of what he calls the "more or less important cultures" includes a list of no fewer than sixty different peoples from across North, Central and South America, Asia, Indonesia, Melanesia and Polynesia (Covarrubias 1940). Arranged around the Pacific Basin, the different symbolic representations reach out to one another across what no longer appears to be such a vast expanse. So too does the different subject matter of each map and its various cultural-geographic areas resonate with those across the room, above the elliptical fountain. As visitors move about within the "spatial envelope" created by these "genuine modern codices," they face west from San Francisco Bay, where Covarrubias asks them to contemplate the historical-geographical cycles of human migration, circling back across the Pacific and through Asia to where the human story began. 


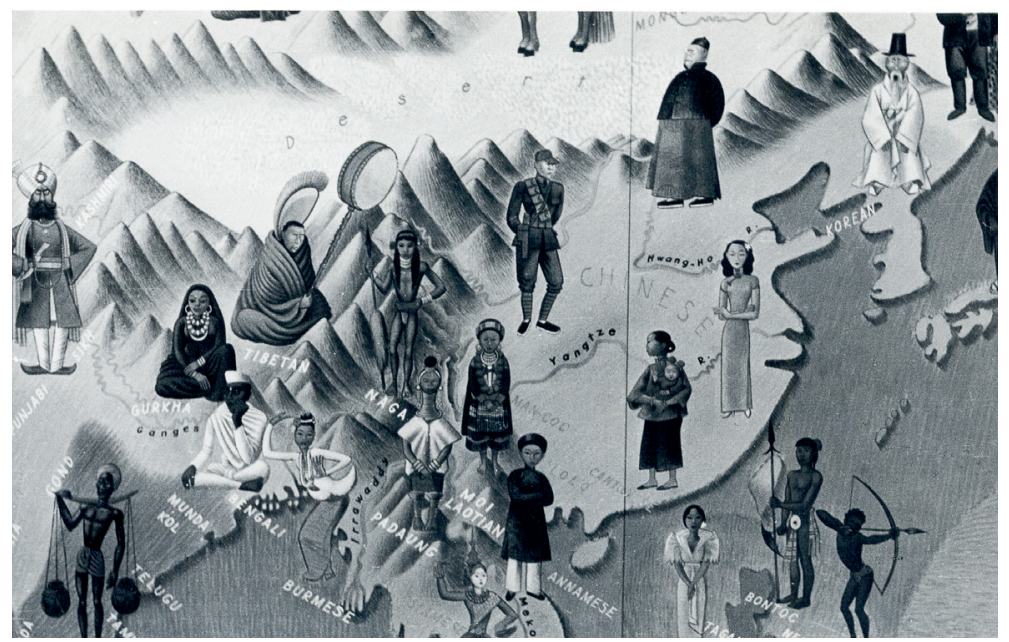

Fig. 2. Miguel Covarrubias, detail of Asia, Peoples of the Pacific, from Pageant of the Pacific, 1940. Courtesy of the Archivo Miguel Covarrubias. Sala de Archivos y Colecciones Especiales, Dirección de Bibliotecas, Universidad de las Américas Puebla.

As Covarrubias would write in Indian Art of Mexico and Central America, ancient Mesoamerican codices are not all that far removed from contemporary graphic communication. He observes:

The Mixtec artists told stories of the most complex nature with stylizations of human beings, gods, animals, plants, mountains, pools, clouds, and all sorts of accessory objects and symbols, very much like our own comic strips, with standard postures and conventions [...]. These

One World

The Americas Everywhere elements, though always highly stylized, are always endowed with a realistic touch that permits recognition of whatever is represented. (1957: 302)

This quality is clearly present in all of Covarrubias's maps, but the Pageant of the Pacific provides a much larger geographic area in which to explore them, as Covarrubias extends his canvas far beyond the Pacific Rim, including cultures from the shores of the Indian and Atlantic Oceans and well inland among the mountains of Tibet and the Great Plains of the United States. Although he never provides a firm definition of the "Pacific Area," nor any elaboration for why he chose specific cultures, there is another clue to his thinking in his description of the mural, Economy of the Pacific (see fig. 3). It is there that he writes: "Trade routes, not shown 
in this map, are great arteries that branch out toward the many ports on the area" (1940). The list tellingly includes the Atlantic ports of New York, Buenos Aires and Rio de Janeiro alongside those important ports that open their harbors onto the waters of the Pacific, such as San Francisco, Valparaiso, Osaka, Shanghai, Hong Kong, Manila and Melbourne, among others.
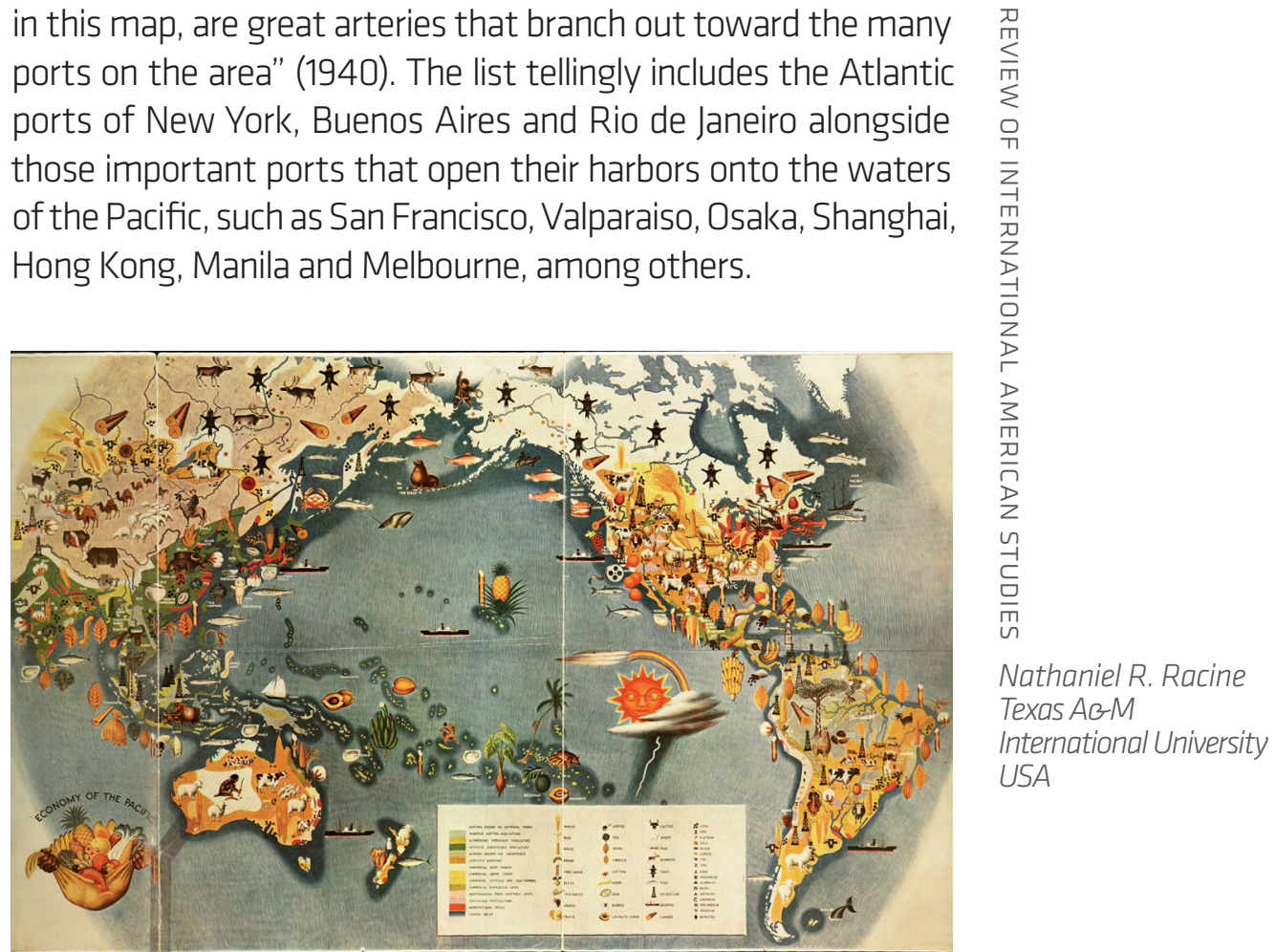

Fig. 3. Miguel Covarrubias, Economy of the Pacific from Pageant of the Pacific, 1940. Courtesy of the Archivo Miguel Covarrubias. Sala de Archivos y Colecciones Especiales, Dirección de Bibliotecas, Universidad de las Américas Puebla.

That these ports are connected despite the particulars of their regional geography can be readily understood by any audience then or now-especially within the context of pan-Pacific idealism. Whatever the given product may be, there is a market for it elsewhere in a globalizing world. In the maps Art Forms of the Pacific Area and Native Dwellings of the Pacific Area, Covarrubias's primary concern seems to be with the representation of the ancient and indigenous cultures of these continents-and therefore focused on the past. Yet, in Native Means of Transportation in the Pacific Area, he includes the China Clipper, a modern aircraft operated by Pan American Airways as the first commercial transpacific airmail service from San Francisco to Manila via Honolulu, Midway Island, Wake Island and Guam. Covarrubias describes the China Clipper as "stand[ing] as a climax and a symbol of the aims of the Pacific 
Area-bringing Asia to America and America to Asia in five days" (1940). The inclusion of modern aircraft and its capabilities serves to remind the audience that they are merely part of a much larger process of cultural exchange. The more rustic types of transportation among which it is situated, along with the native dwelling types and art forms of the other mural-maps, presents an iconography in which no viewer can possibly ignore the historic gradient of cultural variations and similarities.

The same can be said of the symbolic representations and ideas contained in Peoples of the Pacific. ${ }^{8}$ The representations Covarrubias provides in Peoples of the Pacific demonstrate his lifelong interests in the traditional costuming of the peoples native to Asia, the Pacific islands and the Americas. Through many other figures, however, he simultaneously illustrates the modern world. In Asia, for instance, the viewer will find a Chinese soldier in the uniform of the National Revolutionary Army (see fig. 2). Despite distance in time, the modern citizens of North America populate the same landmass as those native peoples in more traditional dress-and perhaps the most striking contrasts are found in the "Easterner," a businessman in New York, reclining in his rolling chair with a cigar, or the "Californian" lounging on the West Coast with her bright blonde hair, sunglasses and white bikini (see fig. 4). Nevertheless, between these comic commentaries on modern materialism and the more dignified presentation of Native American peoples, one finds other 'traditional' peoples insofar

One World The Americas Everywhere as the contemporary folk culture of the Americas is concerned. One can cite the "Mexican" figure in his charro suiting and his northern counterpart, the "Westerner," who rides a bareback bronco (see figs. 4 and 5). ${ }^{9}$ Indeed, upon closer inspection, the inclusion of other figures such as the "Middle-Westerner," the "North-West Canadian" and the "Southern Negro," suggests that the wide array

8. A commentary similar to that described here can be found in Economy of the Pacific, which is dominated by traditional agricultural activities (alongside those of fisheries and forestry) liberally sprinkled with oil rigs and container ships, two ubiquitous symbols of the modern world of industrial and extractive economies (see fig. 3).

9. A detail of South America (not included here) would show yet another counterpart, the "Caucho." 


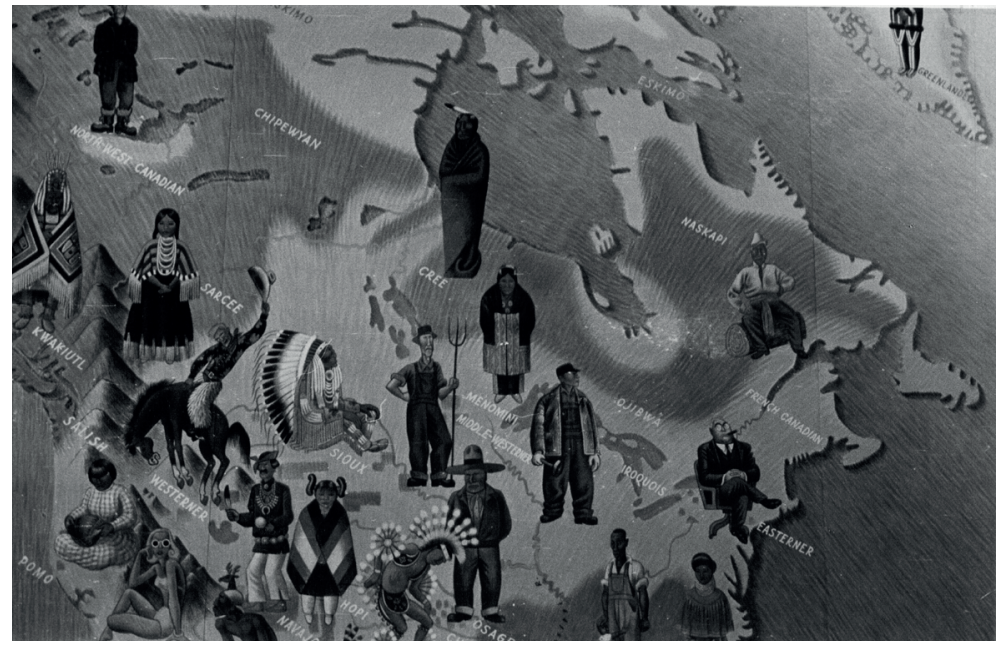

Fig. 4. Miguel Covarrubias, detail of North America, Peoples of the Pacific, from Pageant of the Pacific, 1940. Courtesy of the Archivo Miguel Covarrubias. Sala de Archivos y Colecciones Especiales, Dirección de Bibliotecas, Universidad de las Américas Puebla.

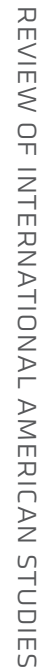

Nathaniel R. Racine Texas AaM

International University USA

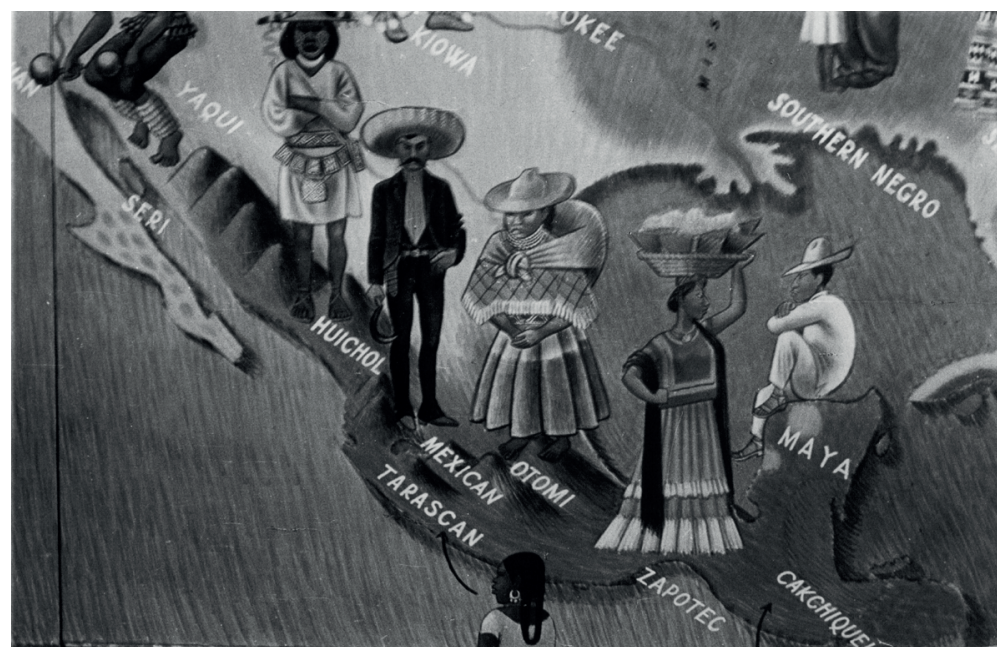

Fig. 5. Miguel Covarrubias, detail of North America, Peoples of the Pacific, from Pageant of the Pacific, 1940. Courtesy of the Archivo Miguel Covarrubias. Sala de Archivos y Colecciones Especiales, Dirección de Bibliotecas, Universidad de las Américas Puebla. 
of peoples and the historical progression they represent would seem to be fairly well-balanced across cultures from ancient to modern. The range of figures included reminds the viewer that, although the juxtapositions are sometimes bizarre, none can ever escape the cultural presence and implication of the others. ${ }^{10}$

Such is the underlying sensibility present in all of Covarrubias' maps, as Tomás Ybarra-Frausto writes in his essay, "Miguel Covarrubias: Cartógrafo" (1987), "[r]ather than seeing borders as points of division, he envisioned them as a space of contact and communication" (qtd. in Williams 1994: 156). It is from this perspective that Covarrubias is writing when he describes Native Dwellings of the Pacific Area. In the first sentence of his overview, he writes: "Climate and raw materials available are of course the principal factors determining the native types of dwellings, however one must not overlook other elements such as cultural connections, living habits, traditional forms and styles and purposes of dwellings" (1940). It is in the shift from the first to the second part of this statement where one hears Covarrubias echoing the changing intellectual climate of his era. It is the same shift from environmental determinism toward environmental possibilism that Sauer defined, emphasizing human agency in the ways people act and interact within and across different geographic areas. The fate of humankind is not determined by external forces and the responsibility shared among cultures cannot be evaded or ignored. For this reason, the geographer $\mathrm{D}$. W. Meinig describes

One World The Americas Everywhere Sauer's approach as "Deeply grounded in science, yet speculative,

10. It is here that some of Covarrubias's ideas show their age. In his description of Peoples of the Pacific, Covarrubias writes that "The old concept of mankind as divided by color lines into four great races [... is obsolete today among anthropologists." Nonetheless, he adopts a system of categorization equally outmoded today. He continues: "for the sake of convenience and based upon definite physical characteristics [...] anthropologists now divide the peoples of the earth into three major groups: Mongoloids, Caucasoids, and Negroids, with endless variations" (1940). Despite the racist terminology, however, the reader understands it to be the then-current language of anthropology. Later in his description, Covarrubias notes that "the white Latin American[s] [... ] are not shown on this map" (1940) He does not comment further, but Covarrubias is aware of the colonialist implications of the terminology and the content of his mural-map would partly seem to mitigate that same legacy. 
reflective, and critical, expressing his strong convictions about some grand themes of man and the earth [...] his view that geography at its best must carry a message for mankind, it becomes a form of moral philosophy" (1983: 319).

In his Pageant of the Pacific, Covarrubias paints the ocean a rich blue color, still and peaceful. In the context of Pacific House, arranged around the relief map and the fountain at its center, one can ignore the European Theater of the Second World War just beyond the fringes of the mural-maps. Although war had already broken-out in Asia and the Pacific Theater would soon extend to Pearl Harbor, Covarrubias's vision is not naive but, rather, presents the "grand themes" of human culture and civilization. Another possibility for the world can be seen here, but it implores its viewers to imagine it. In its own way, then, Covarrubias's cartography offers its own message and moral philosophy.

A well-traveled man with wide-ranging interests, Covarrubias would always return to his country of birth, remaining deeply invested in understanding how Mexico's own regions fit together and how Mexico fits into the larger world. Yet, it would be a mistake to view these as contradictory impulses. This is the topic of Mexico South which would expand outward into North America more generally in The Eagle, the Jaguar, and the Serpent-how world cultures, across the gradations of geographical scale, all fit together. It is the constant balance between the local, regional, continental and global that is consistently displayed in Covarrubias's work and that is of utmost importance. When taken together, the diverse projects in which Covarrubias was involved contain a constellation of ideas that reveal a vision of human culture in which history and geography are fully integrated-Covarrubias's Pageant of the Pacific, along with his other illustrated maps, depict both past and present expressions of culture against the diversity of ecologies, natural resources and physical environments in the places where they are to be found. In his maps the geography is more than mere background, it is instead the setting and medium for human activity.

A confluence of factors-a changing vision and understanding of human culture, a modernizing world that continues to shrink once-vast distances, the growing conflict that would eventually 
erupt into the Second World War-can be observed on the walls of Pacific House. Further south along California's shores, the interconnectedness of it all was phrased differently by John Steinbeck and Ed Ricketts in their Log from the Sea of Cortez (1951), first published in 1941 as the narrative component of their Sea of Cortez: A Leisurely Journal of Travel and Research. It chronicles an expedition of marine biologists in the Gulf of California at a moment almost exactly contemporaneous with Covarrubias's Pageant of the Pacific. In the introduction to the book, the authors write:

[...] if we seem a small factor in a huge pattern, nevertheless it is of relative importance. We take a tiny colony of soft corals from a rock in a little water world. And that isn't terribly important to the tide pool. Fifty miles away the Japanese shrimp boats are dredging with overlapping scoops, bringing up tons of shrimps, rapidly destroying the species so that it may never come back, and with the species destroying the ecological balance of the whole region. That isn't very important in the world. And thousands of miles away the great bombs are falling and the stars are not moved thereby. None of it is important or all of it is. (1995: 3)

The same sensibility is found in Covarrubias's Pageant of the Pacificand, to a certain degree, in all his maps. Whatever the theme, subject or field of study to which a map may pertain, he constantly strikes out into the vastness of the world and its continents, moving through the regions and localized cultures that form a substrate through which human agency has shaped the world it inhabits. Throughout his work, Covarrubias demonstrates the possibilities

One World The Americas Everywhere of "scale-jumping" by simultaneously considering the international and the local in terms of the reciprocity among human cultures and between human beings and their physical environments. Its scope is broad-from architecture to art to economics to fauna and flora to people to transportation-and it is anthropocentric and geographical and interdisciplinary. Covarrubias illustrates the richness and depth found in the interconnectedness of human culture that might otherwise go unnoticed when seen through the lens of any one disciplinary perspective. 
WORKS CITED

Covarrubias, Miguel. The Eagle, the Jaguar, and the Serpent: Indian Art of the Americas: North America: Alaska, Canada, the United States. Alfred A. Knopf, 1954.

----- Indian Art of Mexico and Central America. Alfred A. Knopf, 1957.

------. Island of Bali. Alfred A. Knopf, 1942.

------. Mexico South: The Isthmus of Tehuantepec. Alfred A. Knopf, 1946.

------ "Mural de Pacific House, Economy of the Pacific." Photomechanical reproduction. Exposición UDLAP: Carpeta III-Caricaturas, fotografías y notas. núm. de inv. 31219. Archivo Miguel Covarrubias; Sala de Archivo y Colecciones Especialies de la UDLAP, Universidad de las Américas Puebla, Cholula, Pue., México.

------. "Mural de Pacific House, Peoples of the Pacific." Silver gelatin print. Exposición UDLAP: Carpeta III-Caricaturas, fotografías y notas. núm. de inv. 32842. Archivo Miguel Covarrubias; Sala de Archivo y Colecciones Especialies de la UDLAP, Universidad de las Américas Puebla, Cholula, Pue., México.

------. "Mural de Pacific House, Peoples of the Pacific" [detail of Asia]. Silver gelatin print. Exposición UDLAP: Carpeta IIICaricaturas, fotografías y notas. núm. de inv. 32847. Archivo Miguel Covarrubias; Sala de Archivo y Colecciones Especialies de la UDLAP, Universidad de las Américas Puebla, Cholula, Pue., México.

------. "Mural de Pacific House, Peoples of the Pacific" [detail of Mexico]. Silver gelatin print. Exposición UDLAP: Carpeta IIICaricaturas, fotografías y notas. núm. de inv. 32842. Archivo Miguel Covarrubias; Sala de Archivo y Colecciones Especialies de la UDLAP, Universidad de las Américas Puebla, Cholula, Pue., México.

-----. "Mural de Pacific House, Peoples of the Pacific" [detail of North America]. Silver gelatin print. Exposición UDLAP: Carpeta III-Caricaturas, fotografías y notas. núm. de inv. 31222. Archivo Miguel Covarrubias; Sala de Archivo y Colecciones Especialies de la UDLAP, Universidad de las Américas Puebla, Cholula, Pue., México. 
------. Pageant of the Pacific. Pacific House, 1940.

Fishkin, Shelly Fisher. "Crossroads of Cultures: The Transnational Turn in American Studies-Presidential Address to the American Studies Association, November 12, 2004." American Quarterly, vol. 57, no.1, pp. 17-57. https://doi.org/10.1353/aq.2005.0004

Folgarait, Leonard. Mural Painting and Social Revolution in Mexico, 1920-1940: Art of the New Order. Cambridge UP, 1998.

Jackson, Joseph Henry. A Trip to the San Francisco Exposition with Bobby and Betty. Robert M. McBride and Company, 1939.

James, Jack and Earle Voland. Treasure Island, "The Magic City," 19391940; The Story of the Golden Gate International Exposition. Pisani Printing and Publishing Company, 1941.

Lutkehause, Nancy C. "Miguel Covarrubias and the Pageant of the Pacific: The Golden Gate International Exposition and the Idea of the Transpacific, 1939-1940." Transpacific Studies: Framing an Emerging Field. U of Hawaii P, 2014, pp. 109-133.

López-Casillas, Mercurio, et al. "Geografía de un ilustrador/ Geography of an Illustrator." Miguel Covarrubias: Cuatro miradas/ Four Visions. Translated by Gregory Dechant and Sandra Luna. CONACULTA, 2005, pp. 17-101.

Meinig, D. W. "Geography as an Art." Transactions of the Institute of British Geographers, vol. 8, no. 3, 1983, pp. 314-328. https:// doi.org/10.2307/622047

One World The Americas Everywhere

Parsons, James J. "Carl Ortwin Sauer, 1889-1975." Carl Sauer on Culture and Landscape, edited by William M. Denevan and Kent Mathewson. Louisiana State UP, 2009 pp. 3-8.

Porter, Carolyn. "What We Know We Don't Know: Remapping American Literary Studies." American Literary History, vol. 6, no. 3, 1994, pp. 467-526.

Reeves, E. A. "Van der Grinten's Projection." The Geographical Journal, vol. 24, no. 6, 1904, pp. 670-672. https://doi. org/10.2307/1776259

Sauer, Carl Ortwin. "The Morphology of Landscape." Land and Life: A Selection from the Writings of Carl Ortwin Sauer, edited by John Leighly. U of California P, 1969, pp. 315-350. 
Smith, Roberta. "What to See in New York Art Galleries this Week: Miguel Covarrubias." Review of "Miguel Covarrubias: A Retrospective." The New York Times, 07 February 2019, p. C23. https://www.nytimes.com/2019/02/07/arts/design/whatto-see-in-new-york-art-galleries-this-week.html

Steinbeck, John and E. F. Ricketts. The Log from the Sea of Cortez. Penguin, 1995.

Walls, Laura Dassow. "Literature, Geography, and the Spaces of Interdisciplinarity." American Literary History, vol. 23, no. 4, 2011, pp. 860-872. https://muse-jhu-edu.tamiu.idm.oclc.org/ article/458514

Walsh, Rebecca. The Geopoetics of Modernism. UP of Florida, 2015.

Wilbur, Ray Lyman. "A Pageant of the Pacific." Pageant of the Pacific, by Miguel Covarrubias. Pacific House, 1940.

Williams, Adriana. Covarrubias, edited by Doris Ober. Austin: U of Texas $\mathrm{P}, 1994$.

Nathaniel R. Racine Texas AaM International University USA

Youtz, Philip N. Letter to Miguel Covarrubias. 07 June 1938. Archivero 5/6; Cajón 3/3; Carpeta 475, "Pacific House-General," núm. de doc. 25146. Archivo Miguel Covarrubias; Sala de Archivo y Colecciones Especialies de la UDLAP, Universidad de las Américas Puebla, Cholula, Pue., México. 18 Feb. 2019. 
